\title{
PERKEMBANGAN INSTRUMEN PEMBELAJARAN GAMBAR PEMBELAJARAN BERBASIS LUAR NEGERI UNTUK SISWA
}

\author{
Rebecca ${ }^{\text {1) }}$, Ventje ${ }^{2)}$, Liberman ${ }^{3)}$, Wimpie $^{4)}$, Lily $^{5)}$ \\ 1) Sekolah Tinggi Teologia Abdi Gusti, Nganjuk, Indonesia \\ E-mail: rebecca@sttabdigusti.ac.id \\ 2) Sekolah Tinggi Teologia Abdi Gusti, Nganjuk, Indonesia \\ E-mail:ventje@sttabdigusti.ac.id \\ 3) Sekolah Tinggi Teologia Abdi Gusti, Nganjuk, Indonesia \\ E-mail:liberman@sttabdigusti.ac.id \\ 4) Sekolah Tinggi Teologia Abdi Gusti, Nganjuk, Indonesia \\ E-mail:wimpie@sttabdigusti.ac.id \\ 5) Sekolah Tinggi Teologia Abdi Gusti, Nganjuk, Indonesia \\ E-mail: lily@sttabdigusti.ac.id
}

\begin{abstract}
Abstrak. This research purpose to describe factually learning instrument dan characteristics of learning instrument was developed and acquiring products of drawing learning instrument that are valid and effective.The $R$ and $D$ research design used modifications Thiagarajan 3D model consisting of definition phase, design phase and development phase with research subjects are students of fourth grade at Singosari 2 Elementary School were selected by purposive sampling. The results showed are learning instruments in fact still found mismatch content and components. Drawing learning instruments based on outdoor learning that has five syntax, such as: (1) preliminary, (2) exploration, (3) outdoor learning based school environment, (4) elaboration, and (5) presentation. The validation result of learning instruments obtained an average of 3.46, it is include of very valid category. The result of learning instrument trials shows that: (1) measurement creativity is 7.01 an average, (2) percentage student's activity get $66.87 \%$ in active category, (3) percentage student's response of learning implementation get $83,05 \%$ in very positive category, and (4) percentage teacher's respons of lesson plan get $85 \%$ in very positive category. The final product of the research was in the form of a teacher manual on drawing learning devices based on outdoor learning.
\end{abstract}

Keywords Creativity, Outdoor Learning, Learning Instruments

\section{PENDAHULUAN}

Perangkat pembelajaran adalah seperangkat media atau sarana dalam proses pembelajaran yang digunakan oleh guru untuk membantu mencapai hasil belajar yang telah ditetapkan. Alat pembelajaran dapat berupa silabus, rencana implementasi pembelajaran, lembar aktivitas siswa, instrumen penilaian atau tes hasil belajar, media pembelajaran dan buku teks. Perangkat pembelajaran disiapkan sebelum menerapkan pembelajaran sehingga kegiatan diarahkan dan berjalan dengan baik dalam upaya mencapai tujuan pembelajaran. Proses pembelajaran di unit pendidikan harus dapat diselenggarakan secara interaktif, inspirasional, menyenangkan, menantang, memotivasi siswa untuk berpartisipasi aktif, dan memberikan ruang yang cukup untuk inisiatif, kreativitas dan kemandirian sesuai dengan bakat, minat, perkembangan fisik dan psikologis siswa. Namun, aspek kreativitas belum mendapat 
bimbingan yang cukup, bahkan terkadang diabaikan dalam berbagai mata pelajaran. Hasil pengamatan dan wawancara dengan guru kelas empat di SDN Semolowaru menunjukkan bahwa proses pembelajaran menggambar masih berpusat pada guru. Guru menggunakan strategi ceramah, yaitu guru menjelaskan materi pembelajaran yang disediakan oleh pemerintah kepada siswa dan metode demonstrasi dengan menunjukkan gambar sampel di papan tulis.

$$
\text { Guru belum menguasai teknik }
$$
menggambar. Hasil gambar siswa belum maksimal ditunjukkan oleh hasil gambar yang kurang variatif dan stereotip (pengulangan), yaitu siswa menggambar dengan objek yang sama dan diulang. Jika dalam pembelajaran guru bersedia memberikan kesempatan bagi siswa untuk menemukan konsep, teori aturan, atau pemahaman langsung melalui contoh-contoh yang ditemukan di lingkungan, pembelajaran akan bekerja dengan baik dan kreatif.

Berdasarkan uraian di atas, perangkat pembelajaran menggambar dikembangkan dengan strategi pembelajaran pembelajaran di luar ruangan. Pengembangan alat pembelajaran berbasis outdoor learning diharapkan dapat meningkatkan kualitas penerapan pembelajaran menggambar dan mengembangkan kreativitas siswa. Pengembangan alat belajar pembelajaran terintegrasi dengan mata pelajaran lain dihubungkan dalam tema dan sub-tema (tematik terintegrasi) yang merupakan karakteristik pembelajaran dalam kurikulum 2013.

\section{Literature Review}

Perangkat pembelajaran adalah seperangkat media atau sarana dalam proses pembelajaran yang digunakan oleh guru untuk membantu mencapai hasil belajar yang telah ditetapkan. Alat pembelajaran dapat berupa silabus, rencana implementasi pembelajaran, lembar aktivitas siswa, instrumen penilaian atau tes hasil belajar, media pembelajaran dan buku teks. Perangkat pembelajaran disiapkan sebelum menerapkan pembelajaran sehingga kegiatan diarahkan dan berjalan dengan baik dalam upaya mencapai tujuan pembelajaran.

Berdasarkan Peraturan Menteri Pendidikan dan Kebudayaan (2016: 6), setiap pendidik wajib mengembangkan alat belajar secara lengkap dan sistematis.

Proses pembelajaran di unit pendidikan diadakan secara interaktif, inspirasional, menyenangkan, menantang, memotivasi siswa untuk berpartisipasi aktif, dan menyediakan ruang yang cukup untuk inisiatif, kreativitas dan kemandirian sesuai dengan bakat, minat, perkembangan fisik dan psikologis siswa, (Menteri Peraturan Pendidikan dan Kebudayaan Nomor 22 Tahun 2016 tentang Standar Proses.Namun, aspek kreativitas belum mendapat bimbingan yang memadai, bahkan terkadang diabaikan dalam berbagai mata pelajaran (Tabrani, 2014: 6).

Kreativitas sangat diperlukan bagi siswa untuk dapat mengikuti perubahan yang terjadi dan menghadapi masalah yang semakin kompleks dalam pengembangan ilmu pengetahuan dan teknologi saat ini.sebagai orang atau kelompok, seseorang harus dapat berpikir, membentuk cara-cara baru secara kreatif agar dapat bertahan dan tidak ketinggalan dalam persaingan antara negara dan negara Mengembangkan kreativitas anak sejak usia dini sangat penting karena (1) dapat memanifestasikan (mengaktualisasikan) diri sendiri yang merupakan level tertinggi dari kebutuhan dasar dalam kehidupan manusia (Hukum Maslow), (2) kreativitas sebagai kemampuan untuk menganalisis solusi yang mungkin untuk masalah yang masih kurang diperhatikan dalam pendidikan, (3) kreativitas dapat memberikan kepuasan dan manfaat bagi diri sendiri dan lingkungan, dan (4) kreativitas dalam bentuk ide, penemuan, dan teknologi yang baru di alam, dibutuhkan untuk kemakmuran di era pembangunan (Munandar, 2012: 31- 32). 
Kreativitas paling mudah dikembangkan melalui kegiatan seni karena pada dasarnya seni lebih dekat dengan kreativitas. Dari jenis seni yang ada, menggambar adalah kegiatan yang disukai oleh anak-anak, terlepas dari anak-anak yang memiliki bakat menggambar atau tidak (Tabrani, 2014: 6). Rousseau dengan teori "Kembali ke Alam" menjelaskan bahwa pendidikan anak-anak harus dilakukan di lingkungan alam sehingga anak-anak dapat tumbuh menjadi manusia yang baik (dalam Hamalik, 2004: 194). Ligthart dengan teori "Mengajar Lingkungan Alam" berpendapat bahwa pendidikan harus disesuaikan dengan lingkungan alam yang merupakan semua yang ada di sekitar kita (dalam Hamalik, 2004: 195). Dari pendapat para tokoh tersebut, dapat disimpulkan bahwa lingkungan adalah bagian dasar dari pendidikan atau pengajaran yang penting sebagai dasar untuk mengembangkan model pembelajaran yang berorientasi lingkungan.

Sumber belajar dari lingkungan semakin menambah pengetahuan dan wawasan karena siswa belajar langsung dari sumbernya. Selain itu, kegiatan belajar mungkin lebih menarik bagi siswa karena banyaknya jenis media / objek yang ada di lingkungannya. Husamah (2013: 21 \& 24) mengungkapkan bahwa pembelajaran di luar ruangan mampu memunculkan proses komunikasi, pemecahan masalah, kreativitas, pengambilan keputusan, saling pengertian, menghargai perbedaan, dan cenderung fleksibel dalam proses pembelajaran, memprioritaskan kreativitas dan inisiatif berdasarkan kekuatan penalaran siswa.

Salah satu strategi pembelajaran yang relevan dengan pendapat Bruner, Rousseau dan Ligthart yang digunakan untuk meningkatkan kualitas pembelajaran menggambar dan untuk mencapai tujuan pembelajaran pengembangan kreativitas adalah pembelajaran di luar ruangan. Pembelajaran di luar ruangan adalah pembelajaran yang menggunakan lingkungan untuk menjadi alat belajar. Lingkungan memiliki sumber dan kaya akan media pembelajaran.

\section{Metode}

Penelitian ini adalah penelitian dan pengembangan (Research and Development) yang dimodifikasi dari model pengembangan Thiagarajan, Semmel dan Semmel. Produk yang dikembangkan dalam bentuk menggambar alat belajar berdasarkan pembelajaran di luar ruangan termasuk rencana pelajaran, bahan belajar, mengukur kreativitas siswa dan buku pedoman guru.

Penelitian ini menggunakan model pengembangan perangkat pembelajaran yang dimodifikasi oleh model 3-D Thiagarajan yang mencakup mendefinisikan, merancang, mengembangkan. Model 3-D Thiagarajan dipilih karena tahapan implementasi lebih rinci, sistematis dan melibatkan penilaian ahli sehingga alat pembelajaran telah direvisi berdasarkan penilaian ahli dan saran sebelum uji coba lapangan dilakukan.

Uji coba lapangan dikolaborasikan dengan guru kelas empat SDN Semolowaru sebagai guru teladan. Model guru berfungsi sebagai pelaksana perangkat pembelajaran menggambar berbasis pembelajaran di ruang kelas dan di luar kelas. Model guru diharapkan mampu merespons perangkat pembelajaran menggambar berbasis pembelajaran di luar ruangan yang telah dikembangkan.

Uji coba produk dilakukan dengan menggunakan desain kelompok kontrol pretestposttest. Desain ini digunakan untuk menguji perangkat pembelajaran menggambar. Dalam pelaksanaan uji coba ada dua kelompok, yaitu kelompok eksperimen dan kelompok kontrol. Bentuk desainnya adalah sebagai berikut (Sugiyono, 2013: 416). 


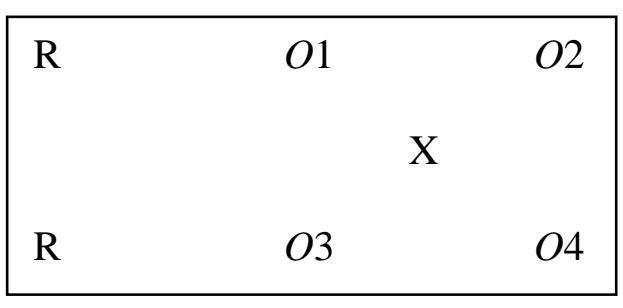

Gambar 2.

Desain Eksperimental dengan Model Pretest Kelompok Kontrol Posttest Sumber: Sugiyono (2013)

Informasi:

$\mathrm{O} 1=$ Kreativitas awal kelompok eksperimen

$\mathrm{O} 2=$ Kreativitas akhir kelompok eksperimen

$\mathrm{O} 3=$ Kreativitas kelompok kontrol awal

$\mathrm{O} 4=$ Kreativitas akhir kontrol kelompok

$\mathrm{X}=$ Pembelajaran Menggambar berdasarkan

Pembelajaran Luar

Ruang Subjek penelitian adalah siswa kelas empat SDN Semolowaru dan SDN Semolowaru Surabaya pada tahun akademik 2015/2016. Subjek tes adalah siswa kelas empat SDN Semolowaru sebagai kelas kontrol dari 19 siswa dan siswa kelas empat SDN Semolowaru sebagai kelas eksperimen dari 21 siswa. Subjek penelitian dipilih menggunakan teknik purposive sampling, yaitu pengambilan sampel dengan mempertimbangkan hal-hal tertentu. Dasar pertimbangan pemilihan subjek penelitian adalah kondisi lingkungan sekolah yang memiliki berbagai jenis tanaman dan dikelilingi oleh bidang, menyesuaikan dengan tema dan sub-tema pembelajaran menggambar kelas IV di Semester 1.

Sumber data adalah subjek dari mana data diperoleh (Arikunto, 2010: 144). Sumber data yang digunakan adalah hasil observasi penelitian pendahuluan, wawancara dengan guru kelas IV, hasil validasi perangkat pembelajaran oleh para ahli, hasil pengukuran kreativitas menggambar siswa, data aktivitas siswa dalam proses pembelajaran, hasil respons guru pada alat pembelajaran dan tanggapan siswa terhadap implementasi pembelajaran. daftar nama siswa kelas empat SDN Semolowaru dan daftar nama siswa kelas empat di SDN Semolowaru, serta rencana pembelajaran menggambar faktual.
Teknik analisis data yang digunakan meliputi:

1. Analisis Validitas Perangkat Pembelajaran. Validasi ahli perangkat pembelajaran menggambar yang meliputi RPP, materi pembelajaran, dan pengukuran kreativitas menggunakan validitas konten. Kriteria untuk mengevaluasi validitas perangkat pembelajaran menggunakan skala 4 , yaitu 4 (sangat valid), 3 (valid), 2 (cukup valid) dan 1 (tidak valid). Hasil validasi ahli dihitung menggunakan skor validasi perangkat rata-rata. Data dalam bentuk skor dan deskripsi saran. Deskripsi saran dirangkum dan dideskripsikan secara naratif untuk dasar revisi perangkat pembelajaran.

2. Analisis Kreativitas Siswa. Aspek kreativitas meliputi kelancaran, keaslian, fleksibilitas, dan detail. Aspek kelancaran terdiri dari tiga indikator. Aspek keaslian terdiri dari dua indikator. Aspek fleksibilitas terdiri dari dua indikator. Aspek detail terdiri dari tiga indikator. Setiap indikator yang dipenuhi diberikan skor 1 sedangkan indikator yang tidak terpenuhi diberi skor 0 dan skor maksimum adalah 10. Kreativitas siswa diukur menggunakan Tes Masuk dengan tingkat kesalahan terbesar 5\%.

3. Analisis Kuesioner Tanggapan Siswa dan Guru Data tanggapan siswa dan guru dihitung dengan menjumlahkan skor yang diperoleh dalam setiap pernyataan pada kuesioner tanggapan.

4. Analisis Data Dokumentasi Analisis data dokumentasi dalam bentuk gambar faktual RPP adalah dengan memeriksa isi setiap komponen RPP dan kesesuaian konten antara komponen RPP. Meninjau isi dari rencana pelajaran didasarkan pada karakteristik pembelajaran, Standar Konten dan Standar Proses dalam kurikulum 2013. Hasil analisis RPP faktual digunakan sebagai dasar untuk mengembangkan alat pembelajaran berdasarkan pembelajaran di luar ruangan. 


\section{Hasil Dan Diskusi}

Perangkat pembelajaran menggambar berbasis pembelajaran di luar ruangan divalidasi oleh validator tematik dan praktisi pendidikan. Hasil rekapitulasi skor validasi ahli pada perangkat pembelajaran berbasis pembelajaran luar ruang yaitu RPP 1 memperoleh rata-rata 3,69 pada kategori sangat baik, RPP 2 memperoleh rata-rata 3,63 pada kategori sangat baik dan RPP 3 memperoleh rata-rata 3,63 pada kelas kategori sangat baik. Sedangkan validitas perangkat pembelajaran adalah 3,65 dalam kategori sangat baik.

Aspek perangkat pembelajaran yang tervalidasi adalah 11 aspek yang terdiri dari: (1) identitas subjek, (2) kompetensi inti, (3) kompetensi dasar, (4) indikator, (5) tujuan pembelajaran, (6) materi pembelajaran, (7) ) metode dan pendekatan pembelajaran, (8) media, alat dan sumber belajar, (9) langkah-langkah pembelajaran, (10) penilaian otentik, dan (11) tata bahasa. Aspek identitas subjek, kompetensi inti (KI) mendapatkan skor tertinggi, yaitu 4. Aspek kompetensi dasar (KD) berada di urutan kedua dengan skor 3,89. Aspek tujuan pembelajaran, metode dan pendekatan pembelajaran, media, alat dan sumber belajar, dan langkah-langkah pembelajaran berada di tempat ketiga dengan skor 3,66. Aspek pembelajaran otentik dan materi penilaian berada di tempat keempat dengan skor 3,44 dan aspek indikator dan tata bahasa berada di urutan kelima dengan skor 3,22. Rata-rata semua aspek adalah 3,62 dalam kategori sangat baik.

Efektivitas perangkat pembelajaran menggambar berbasis pembelajaran di luar ruangan dari hasil uji coba nyata dilihat dari empat aspek, yaitu aktivitas siswa, respon siswa, respon guru dan kreativitas siswa. Hasilnya dari 21 siswa ada 2 siswa $(9,5 \%)$ dalam kategori sangat aktif, ada 16 siswa $(76,2 \%)$ termasuk dalam kategori aktif dan ada 3 siswa (14,3\%) siswa dalam kategori kurang aktif. Melalui pembelajaran menggambar berbasis pembelajaran di luar ruangan dapat meningkatkan aktivitas siswa termasuk kegiatan melihat, kegiatan mendengarkan, kegiatan gerak, kegiatan mental dan kegiatan emosional. Kegiatan lisan, kegiatan menulis, dan kegiatan menggambar perlu ditingkatkan.
Respon siswa untuk belajar memperoleh rata-rata $29,90(83,05 \%)$ dalam kategori sangat positif. Respon tertinggi oleh siswa terkait dengan proses pembelajaran yang tidak membosankan adalah rata-rata 3,72. Respon siswa yang senang terhadap materi pembelajaran diperoleh rata-rata 3,68. Respon dalam mengikuti proses pembelajaran diperoleh rata-rata 3,59. Respon dalam menemukan ide / ide dalam menggambar diperoleh rata-rata 3,54. Respons terhadap suasana belajar yang menyenangkan memperoleh rata-rata 3,45. Respons tentang pembelajaran luar ruang yang menyenangkan diperoleh dengan rata-rata 3,31. Respon tentang kesenangan belajar di lingkungan terbuka diperoleh rata-rata 3,27. Respon terhadap kebahagiaan terhadap pendekatan pembelajaran luar yang digunakan dalam pembelajaran adalah rata-rata 3,09. Respons terhadap cara mengajar guru diperoleh rata-rata 2,9.

Respons guru terhadap alat menggambar berbasis pembelajaran di luar ruangan terdiri dari 9 pernyataan. Alat belajar menggambar berbasis pembelajaran di luar ruangan mudah diterapkan oleh guru, guru difasilitasi dalam melakukan proses pembelajaran, kreativitas siswa dapat dikembangkan melalui pembelajaran menggambar dan format penulisan perangkat pembelajaran menggambar diperoleh skor 4 . Bahasa dan kalimat dalam perangkat pembelajaran, perangkat pembelajaran menggambar berbasis pembelajaran di luar ruangan dapat meningkatkan aktivitas siswa, penilaian perangkat pembelajaran mudah diimplementasikan, cakupan dan kedalaman bahan pembelajaran cukup memadai, perangkat pembelajaran menggambar dapat mengatasi kesulitan ide / ide siswa dalam menggambar dan siswa senang, antusias dan antusias belajar mendapat nilai 3. Secara keseluruhan skor 34 dengan persentase diperoleh $85 \%$ dalam kategori sangat positif.

Uji homogenitas dari data pretest eksperimental dan kelas kontrol menggunakan Uji Levene melalui SPSS 17 dengan tingkat signifikansi\% 5. Data homogen jika nilai signifikansi yang dihitung lebih besar dari 5\%. Hasil pengujian menunjukkan nilai signifikansi data pretest 0,833 dengan hasil $0,833>0,05$, dapat disimpulkan 
bahwa sampel memiliki varians yang sama atau homogen.

Uji homogenitas dari data posttest dari kelas eksperimen dan kontrol menggunakan Uji Levene melalui SPSS 17 dengan tingkat signifikansi\% 5. Data homogen jika nilai signifikansi yang dihitung lebih besar dari $5 \%$. Hasil pengujian menunjukkan nilai signifikansi data posttest sebesar 0,746 dengan hasil 0,746> 0,05 , dapat disimpulkan bahwa sampel memiliki varians yang sama atau homogen. Data yang diperoleh dari kelas kontrol dan eksperimen menunjukkan homogenitas dan tidak terdistribusi normal karena sampel di bawah 30, maka kreativitas siswa dihitung menggunakan uji statistik non-parametrik.

Masuk hasil Tes pada kelas kontrol dengan total 19 siswa, diperoleh hasil siswa yang mengalami penurunan 4 siswa $(21,05 \%)$, siswa yang tidak berubah sebanyak 0 siswa $(0 \%)$, siswa yang mengalami peningkatan dari 15 siswa $(78,95 \%)$, dengan sig tepat. (2-tailed) dari 0,019. Level signifikansi 5\% (0,05), maka harga 0,019 lebih kecil dari 0,05. Kemudian disimpulkan bahwa ada pengaruh positif dan signifikan dari pembelajaran menggunakan media gambar dan video pada pengembangan kreativitas siswa.

Pada kelas eksperimen yang berjumlah 21 siswa, hasil siswa yang mengalami penurunan 1 siswa $(4,76 \%)$, siswa yang tidak mengalami perubahan sebanyak 1 siswa $(4,77 \%)$, siswa yang mengalami peningkatan 19 siswa (90,47\%), dan. Sig kolom yang tepat, (2-tailed) memperoleh angka 0,00 dengan tingkat signifikansi 0,05 sehingga harga 0,00 lebih kecil dari 0,05. Disimpulkan bahwa pembelajaran di luar ruangan memiliki pengaruh positif dan signifikan terhadap pembelajaran.

\section{Hasil dan Diskusi}

Pengembangan Model pengembangan yang digunakan dalam penelitian ini adalah modifikasi dari model 3D Thiagarajan. Tahapan dalam pengembangan alat pembelajaran adalah: (1) fase definisi, (2) tahap desain dan (3) tahap

pengembangan.Tahapanpengembangan perangkat pembelajaran disajikan sebagai berikut:
1. Tahap Mendefinisikan Tahap mendefinisikan bertujuan untuk mendefinisikan dan mendefinisikan kebutuhan belajar. Tahap pendefinisian diperlukan untuk menentukan perencanaan yang tepat dan objektif dalam mengembangkan alat pembelajaran berbasis pembelajaran di luar ruangan untuk mengembangkan kreativitas siswa. Tahap penyempurnaan meliputi:

\section{a. Analisis Front End}

Pengamatan pembelajaran, terutama menggambar di SDN Semolowaru, Surabaya, hasil menunjukkan bahwa metode / teknik pembelajaran yang digunakan oleh guru kurang bervariasi. Guru belum menggunakan media pembelajaran menggambar. Hasil menggambar siswa cenderung stereotip dan kurang variasi. Berdasarkan hasil wawancara dengan guru, sejauh ini pembelajaran telah dilakukan di ruang kelas, belum memanfaatkan lingkungan di sekitar sekolah sebagai sumber dan media pembelajaran. Berdasarkan analisis, pengembangan alternatif perangkat pembelajaran berbasis pembelajaran di luar ruangan dipilih dengan memanfaatkan lingkungan di sekitar sekolah seperti tanaman, ladang atau kebun dan menyiram tanaman dan bunga sebagai sumber dan media untuk belajar. Siswa diharapkan menggambar sesuai tema dan sub tema yang telah ditentukan sesuai dengan karakteristik dan kemampuan masing-masing siswa secara kreatif. Masalah dan solusi telah ditemukan, langkah-langkah pengembangan dapat dilanjutkan dengan tahap analisis siswa.

\section{b. Analisis Siswa}

Siswa bertujuan untuk mengembangkan perangkat pembelajaran sesuai dengan karakteristik siswa. Berdasarkan pengamatan pada implementasi pembelajaran di SDN Semolowaru, siswa merasa senang dan antusias dalam menggambar, tetapi gambar yang dibuat masih stereotip (berulang) dan kurang variasi. Kreativitas siswa terutama dalam pembelajaran menggambar belum diperhatikan. Berdasarkan analisis tersebut, digunakan inovasi pembelajaran pembelajaran luar ruang yang memanfaatkan 
lingkungan sebagai sumber dan media pembelajaran bagi siswa untuk mengembangkan kreativitas siswa.

\section{a. Analisis Konsep Analisis}

konsep bertujuan untuk mengidentifikasi dan menyusun materi pembelajaran menggambar yang relevan yang diajarkan berdasarkan analisis ujung depan. Materi pembelajaran yang dibuat adalah materi pada semester IV kelas 1. Materi gambar tersebar dalam beberapa tema dan sub tema, yaitu: (1) tema Kepedulian terhadap Makhluk Hidup, sub tema Hewan dan Tumbuhan di Lingkungan Sekolah, pembelajaran keenam , (2) Berbagai tema Pekerjaan, sub-tema pekerjaan, pembelajaran ke-4, dan (3) tema berbagai pekerjaan, sub-tema barang dan jasa, pembelajaran ke-5. Bahan gambar terintegrasi dengan bahan pembelajaran lainnya. Dalam RPP 1 terdiri dari pelajaran SBdP dan Bahasa Indonesia dengan materi tentang tanaman. RPP 2 terdiri dari studi sosial, Bahasa Indonesia, SBdP dan IPA dengan bahan sumber daya alam. RPP 3 terdiri dari pelajaran Kewarganegaraan, Bahasa Indonesia, SBdP dan IPA dengan materi tentang air.

\section{b. Analisis}

Tugas Analisis tugas adalah identifikasi tugas yang dibutuhkan dalam pembelajaran yang sesuai dengan kompetensi inti dan kompetensi dasar kurikulum 2013. Tugas yang diberikan kepada siswa adalah: (1) mempresentasikan tugas-tugas seperti menjawab pertanyaan berdasarkan membaca teks atau hasil diskusi berdasarkan pengamatan yang telah dilakukan secara individu dan kelompok di depan kelas, dan (2) menggambar sesuai dengan tema dan subtema yang telah ditentukan secara kreatif.

\section{c. Perumusan Tujuan}

Pembelajaran Perumusan tujuan pembelajaran mengacu pada kompetensi inti (KI), kompetensi dasar (KD) dan indikator pencapaian kompetensi yang telah disiapkan. Pertemuan RPP 1 adalah (1) Dengan mengamati, siswa dapat menggambar tanaman di sekitar lingkungan rumah secara kreatif, (2) Dengan mengamati, mempresentasikan hasil gambar tentang bagian-bagian tanaman dan fungsinya dengan cermat. Rapat Rapat Implementasi Rencana 2 adalah (1) Dengan mengamati gambar, siswa dapat menjelaskan hubungan berbagai sumber daya alam dengan jenis-jenis pekerjaan dengan cermat, (2) Dengan mengamati gambar kerja, siswa dapat membedakan pekerjaan yang menghasilkan benda. dan pekerjaan yang menghasilkan jasa dengan hatihati, (3) Dengan membaca teks sumber daya alam, siswa dapat membedakan sumber daya alam terbarukan dan sumber daya alam yang tidak dapat diperbarui dengan hati-hati, (4) Dengan mengamati alam, siswa dapat menggambar alam berdasarkan pada instruksi yang diberikan oleh guru secara kreatif, (5) Dengan membaca teks sumber daya alam, siswa dapat menemukan informasi tentang sumber daya alam (bambu, kayu dan logam) dengan cermat, dan (6) Setelah membaca teks sumber daya alam, siswa mampu menjelaskan hubungan sumber daya alam dengan kondisi lingkungan di mana orang hidup dalam bahasa yang sopan. Rapat Rapat Implementasi Rencana 3 adalah (1) Dengan berdiskusi, siswa dapat merefleksikan sikap tentang penggunaan air dalam kehidupan sehari-hari dengan cermat, (2) Dengan kegiatan membaca, siswa dapat menggali informasi pada teks laporan tentang penggunaan sumber daya air dengan rasa keinginan tahu, (3) Dengan mengamati lingkungan, siswa membuat gambar kreatif terkait air.

\section{Fase Desain Fase}

Desain bertujuan untuk merancang perangkat pembelajaran. Langkah-langkah dalam tahap ini adalah sebagai berikut:

\section{a. PemilihanPemilihan}

Mediamedia dilakukan untuk mengidentifikasi media pembelajaran yang relevan dengan karakteristik materi. Media pembelajaran yang dipilih disesuaikan dengan analisis konsep, analisis tugas, dan karakteristik siswa. Media yang dipilih dalam penelitian ini adalah (1) tanaman di sekitar sekolah, (2) gambar 
karya siswa, (3) teknik video mewarnai gambar menggunakan krayon, (4) meja, kursi, lemari dan pintu, (5) bidang tampilan / kebun di sekitar sekolah; dan (6) mencuci tangan dan menyiram bunga di sekolah. Alat yang digunakan dalam mewarnai gambar adalah krayon, karena memiliki lebih banyak variasi warna dibandingkan dengan pensil warna. Penggunaan krayon bertujuan untuk meningkatkan pengetahuan, pengalaman, dan keterampilan siswa di samping pensil warna dalam mewarnai gambar.

\section{b. Desain Awal Desain}

awal perangkat pembelajaran meliputi rencana pelajaran, bahan pembelajaran dan mengukur kreativitas. Implementasi rancangan awal dapat dijelaskan sebagai berikut:

\section{Rencana Implementasi Pembelajaran Rencana Implementasi}

Pembelajaran (RPP) disusun setelah pemetaan kompetensi dasar dan indikator pencapaian kompetensi dilakukan sesuai dengan tema dan sub-tema yang telah ditentukan. Pemetaan diperlukan untuk memfasilitasi persiapan rencana pelajaran. Komponen RPP terdiri dari identitas sekolah, yaitu nama satuan pendidikan, identitas subjek atau tema / subtema, kelas / semester, materi pelajaran, alokasi waktu, tujuan pembelajaran kompetensi dasar dan indikator pencapaian kompetensi, materi pembelajaran, metode pembelajaran, media pembelajaran, sumber belajar, langkah pembelajaran, dan penilaian hasil pembelajaran.

\section{Materi Pembelajaran Materi}

pembelajaran disusun dan dikembangkan sesuai dengan rencana implementasi pembelajaran yang telah disiapkan. Materi dalam RPP adalah pertemuan pertama tanaman di lingkungan rumah. Materi dalam pertemuan kedua RPP tentang jenis pekerjaan. Materi RPP untuk pertemuan ketiga adalah tentang barang dan jasa.

\section{Pengukuran}

Kreativitas Kreativitas terdiri dari 4 subkemampuan, yaitu kelancaran, keaslian, fleksibilitas, dan detail. Kefasihan adalah banyaknya ide atau ide yang muncul. Fleksibilitas adalah kemampuan untuk melihat masalah dari berbagai arah. Otentisitas adalah ide atau ide yang berbeda dari ide kebanyakan orang.

Detail adalah kemampuan untuk mengembangkan ide hingga selesai dan detail.

\section{Tahap Pengembangan Tahap}

pengembangan adalah tahap untuk menghasilkan perangkat pembelajaran menggambar berbasis pembelajaran yang valid dan efektif untuk mengembangkan kreativitas siswa. Tahap ini terdiri dari 3 tahap, yaitu validasi ahli, uji coba terbatas dan uji coba nyata. Deskripsi ketiga tahapan tersebut adalah sebagai berikut:

\section{a. Validasi Pakar}

Perangkat Pembelajaranyang telah dirancang kemudian divalidasi oleh para ahli. Validasi dari para ahli bertujuan untuk mendapatkan perangkat pembelajaran yang valid dari aspek format, bahasa, dan konten. Hasil validasi ahli digunakan sebagai uji kelayakan dan input untuk meningkatkan alat pembelajaran yang telah dikembangkan.

\section{b. Uji Coba Terbatas Uji}

terbatas dilakukan untuk 9 siswa kelas V SDN Semolowaru. Pelaksana uji coba terbatas pada guru kelas lima di SDN Semolowaru sebagai guru teladan. Model guru dipilih untuk mengetahui tanggapan guru terhadap perangkat pembelajaran menggambar dan kendala yang dialami dalam pelaksanaan pembelajaran menggambar pembelajaran terbatas.

Hasil yang diperoleh dalam uji coba terbatas untuk mencakup aktivitas siswa, respons siswa, respons guru, dan kreativitas.

Aktivitas siswa pada pembelajaran belajar terbatas diperoleh rata-rata 22,14, termasuk dalam kategori aktif dengan jumlah siswa 9 anak. Respon siswa terhadap pembelajaran 
menggambar berdasarkan pembelajaran luar diperoleh rata-rata 29,2 yang termasuk dalam kategori sangat positif. Respons guru terhadap pembelajaran menggambar berbasis pembelajaran di luar ruangan berada dalam kategori sangat positif, dari respons rata-rata $80 \%$. Perangkat pembelajaran menggambar berbasis pembelajaran di luar ruangan dapat dibuat mudah untuk diterapkan dalam pembelajaran, dapat mengembangkan kreativitas dan kegiatan siswa, membuatnya lebih mudah bagi siswa untuk menemukan ide / ide dalam menggambar dan siswa menjadi bahagia, semangat, bersemangat dalam mengikuti proses pembelajaran. Kreativitas siswa sebelum penerapan pembelajaran luar diperoleh rata-rata 5 , setelah belajar pembelajaran luar diperoleh rata-rata 6,56 .

Hasil tes tanda kreativitas siswa diperoleh hasil, 1 siswa mengalami penurunan skor, sedangkan 8 siswa mengalami peningkatan skor kreativitas siswa. Sig kolom yang tepat (2-tailed) memperoleh angka 0,012, dengan tingkat kesalahan 5\% (0,05), maka harga 0,012 lebih kecil dari 0,05. Maka dapat disimpulkan bahwa ada pengaruh positif dan signifikan pembelajaran outdoor terhadap pengembangan kreativitas siswa.

\section{c. Uji coba}

nyata Tes aktual dilakukan untuk mengukur kreativitas siswa, aktivitas siswa, respons siswa terhadap penerapan pembelajaran di luar ruangan dan respons guru terhadap perangkat pembelajaran menggambar pembelajaran di luar ruangan yang telah disiapkan. Uji coba nyata dilakukan pada siswa kelas empat SDN Semolowaru pada tahun akademik 2015/2016 sebagai kelas kontrol dan siswa kelas empat di SDN Semolowaru pada tahun akademik 2015/2016 sebagai kelas eksperimen. Kelas kontrol adalah 19 siswa dan kelas eksperimen adalah 21 siswa. Implementasi pembelajaran menggambar di kelas kontrol dilakukan di kelas dengan memanfaatkan media gambar dan video sebagai perbandingan dengan kelas eksperimen.

Pilot sesungguhnya di kelas eksperimen adalah guru kelas empat di SDN Semolowaru sebagai guru teladan. Model guru dipilih untuk mengetahui respon guru terhadap perangkat pembelajaran menggambar dan implementasi pembelajaran menggambar yang sebenarnya. Persiapan yang dibuat untuk guru model sebelum uji coba yang sebenarnya adalah: (1) menyiapkan alat belajar menggambar, media, alat dan sumber belajar, (2) penjelasan tentang menggambar, pembelajaran di luar ruangan dan kreativitas, (3) mengarahkan langkah-langkah pembelajaran dan menghambat pelaksanaan menggambar kegiatan belajar yang ditemukan dalam uji coba terbatas. Kegiatan pembelajaran percontohan berdasarkan pembelajaran luar sebenarnya dilakukan 3 kali.

\section{DISKUSI}

Pembahasan hasil penelitian meliputi: (1) perangkat pembelajaran faktual, (2) karakteristik alat pembelajaran berdasarkan pembelajaran luar ruangan untuk kurikulum kelas IV 2013, (3) validitas perangkat pembelajaran menggambar pembelajaran berbasis luar ruang, (4) efektivitas perangkat pembelajaran menggambar berdasarkan pembelajaran di luar ruangan dalam mengembangkan kreativitas siswa, dan (5) perangkat pembelajaran menggambar di luar pembelajaran dalam mengembangkan kreativitas siswa.

\section{a. Perangkat Pembelajaran Faktual}

Beberapa kriteria untuk perangkat pembelajaran yang baik adalah (1) RPP memenuhi komponen dan struktur minimum, yaitu tujuan pembelajaran, bahan pembelajaran, metode pembelajaran, langkah-langkah pembelajaran, sumber belajar dan penilaian hasil pembelajaran,

(2) komponen RPP secara fungsional saling berhubungan dan (3) RPP menyajikan cakupan, kedalaman, tingkat kesulitan, dan urutan materi yang sesuai dengan tingkat perkembangan siswa sekolah dasar dan memperhitungkan perkembangan ilmu pengetahuan terbaru, teknologi dan seni dalam kehidupan nyata, dan peristiwa yang terjadi, (4) RPP menyajikan metode dan langkah-langkah pembelajaran yang aktif, kreatif, efektif dan menyenangkan, (5) RPP menyajikan penilaian hasil pembelajaran dengan berbagai aspek dan teknik penilaian, (6) RPP menyajikan beragam, sumber belajar yang tersedia dengan mudah tersedia di lingkungan 
sekitar siswa dan sekolah, hasil yang murah, dan efektif, dan (7) seluruh komponen RPP dapat digunakan oleh guru atau disesuaikan dengan dinamika perubahan yang terjadi di sekolah dan tuntutan komunitas (Komalasari, 2013: 197).

Alat pembelajaran yang disusun oleh guru kelas empat di SDN Semolowaru sudah cukup baik tetapi masih ada beberapa kekurangan, termasuk (1) domain spiritual KD dan sikap belum dimasukkan, (2) kurangnya kompatibilitas antara komponen RPP seperti bahan belajar, media, alat dan sumber belajar, langkah pembelajaran dan penilaian. Alat pembelajaran yang ada perlu direvisi dan dikembangkan dengan pendekatan pembelajaran yang dapat menciptakan proses belajar yang aktif, kreatif, efektif dan menyenangkan. Salah satu pendekatan pembelajaran yang dapat digunakan untuk mengembangkan perangkat pembelajaran adalah pembelajaran di luar ruangan dalam upaya mengembangkan kreativitas siswa.

\section{a. Karakteristik Perangkat Pembelajaran Menggambar Luar}

Ruang Langkah-langkah kegiatan pembelajaran dan menggambar materi pembelajaran berdasarkan pembelajaran luar ruang yang dikembangkan terkait dengan situasi nyata. Siswa berinteraksi dengan objek dan lingkungan secara langsung sehingga pembelajaran dapat bermakna bagi kehidupan siswa. Selain itu, pembelajaran di luar ruangan memiliki keuntungan sebagai berikut: (1) siswa melakukan lebih banyak kegiatan yang secara tidak langsung melibatkan kolaborasi antara teman-teman, (2) memunculkan proses komunikasi, pemecahan masalah, kreativitas, pengambilan keputusan, saling pengertian dan menghargai perbedaan dan ( 3) lebih fleksibel, mengutamakan kreativitas dan inisiatif berdasarkan kekuatan penalaran siswa (Husamah, 2013: 21 \& 24), (4) mengajar di luar kelas dapat meningkatkan motivasi, komunikasi dan partisipasi di antara siswa, (5) siswa dapat berbagi pengalaman yang diperoleh di lingkungan sekitar dan dapat menjadi titik awal program pembelajaran di kelas, (6) mengajar di luar kelas dapat mengembangkan dan memperkuat pembelajaran yang telah diperoleh siswa di kelas (Fagerstam, 2014: 56), dan (7) di luar ruangan belajar dapat memberikan pengalaman langsung yang memberi kesan mendalam pada siswa.

Berdasarkan karakteristik perangkat pembelajaran di atas, dapat dikatakan bahwa perangkat pembelajaran yang dikembangkan sesuai dengan karakteristik pembelajaran kurikulum 2013 adalah pendekatan ilmiah terhadap pengembangan domain keterampilan, yaitu kreativitas. Pembelajaran di luar ruangan dan alat pembelajaran kontekstual dapat membantu siswa lebih mudah memahami materi pembelajaran dan menghubungkan pengetahuan mereka dengan situasi nyata sehingga pembelajaran dapat lebih bermakna bagi siswa.

\section{b. Validitas Perangkat Pembelajaran Menggambar Berbasis Pembelajaran Outdoor}

Produk perangkat pembelajaran menggambar berbasis pembelajaran di luar ruangan yang dikembangkan terdiri dari RPP, materi pembelajaran, dan pengukuran kreativitas. Perangkat pembelajaran dikembangkan menggunakan modifikasi model 3D Thiagarajan yang terdiri dari fase pendefinisian, fase desain, dan tahap pengembangan.

Tahap pendefinisian terdiri dari analisis ujung depan, analisis siswa, analisis konsep, analisis tugas, dan perumusan tujuan pembelajaran. Fase desain terdiri dari tahapan pemilihan media dan desain awal. Tahap pengembangan terdiri dari validasi ahli perangkat pembelajaran, uji coba terbatas dan uji coba nyata. Munandar (2012: 47) dalam penelitiannya dalam mengembangkan perangkat pembelajaran untuk model e-learning Biologi menggunakan modifikasi model 3D Thiagarajan.

Pengembangan perangkat pembelajaran menggunakan modifikasi model 3D Thiagarajan karena tahap pengembangan lebih rinci dan sistematis.

Produk untuk pembelajaran menggambar di luar pembelajaran divalidasi oleh para ahli perangkat pembelajaran dan praktisi pendidikan untuk menilai kelayakan perangkat pembelajaran sebelum diuji secara terbatas. Aspek yang dinilai adalah isi komponen pembelajaran dan perangkat tata bahasa. Hasil validasi oleh pakar perangkat 
pembelajaran, yaitu dosen di Fakultas Pendidikan Universitas Negeri Semarang dan dosen di Fakultas Tarbiyah dan Pelatihan Guru di IAIN Surakarta memberikan penilaian yang sangat baik. Hasil validasi praktisi pendidikan yaitu Kepala Sekolah Dasar Sumbung 1 memberikan penilaian yang sangat baik. Data dari hasil validasi dari tiga ahli dengan kriteria yang sangat baik menunjukkan bahwa perangkat pembelajaran layak untuk diuji pada skala terbatas.

\section{c. Keefektifan Perangkat Pembelajaran Menggambar Berbasis Pembelajaran di Luar Negeri Efektivitas}

perangkat pembelajaran menggambar berbasis pembelajaran di luar ruangan dari hasil uji coba aktual dilihat dari empat aspek, yaitu aktivitas siswa, respons siswa, respons guru, dan kreativitas siswa. Kegiatan siswa yang diamati meliputi kegiatan fisik, psikologis dan sosial. Kegiatan fisik meliputi kegiatan melihat, kegiatan lisan, kegiatan mendengarkan, kegiatan menulis, kegiatan menggambar, kegiatan gerakan. Aktivitas psikis berupa aktivitas mental dan aktivitas emosional. Kegiatan sosial berupa diskusi tentang kegiatan lisan. Berbagai kegiatan siswa muncul dalam pembelajaran karena situasi pembelajaran di luar ruangan berdasarkan pembelajaran menggambar memberikan peluang bagi siswa untuk melakukan berbagai kegiatan pada siswa yang dapat memberikan kontribusi positif terhadap hasil belajar siswa (Rachmawati, 2013: 77).

Uji homogenitas dilakukan untuk mengetahui apakah subjek tes memiliki skor varians yang sama atau tidak di kelas eksperimen dan kelas kontrol sebelum memproses data kreativitas statistik. Hasil uji homogenitas pretest memperoleh nilai signifikansi 0,833 dan data posttest memperoleh nilai signifikansi 0,746 yang memiliki nilai lebih besar dari 0,05 yang menunjukkan bahwa kelas eksperimen dan kontrol memiliki varian yang sama atau homogen. Ini menunjukkan bahwa kreativitas menggambar siswa tidak memiliki perbedaan sebelum menerapkan pendekatan pembelajaran luar ruangan.
Kreativitas dianalisis secara statistik menggunakan rumus Uji Tanda. Hasil Uji Tanda kreativitas siswa di kelas eksperimen, siswa yang skor kreativitasnya meningkat 90,47\%, siswa yang skor kreativitasnya tidak berubah sebesar $0 \%$, siswa yang skor kreativitasnya menurun $4,76 \%$ dan tingkat signifikansi memperoleh skor 0,00 lebih kecil dari 0,05. Tanda Uji Hasil di kelas kontrol, siswa yang skor kreativitasnya meningkat $78,95 \%$, siswa yang skor kreativitasnya tidak berubah sebesar $5 \%$, siswa yang skor kreativitasnya menurun $21,05 \%$ dan tingkat signifikansi yang diperoleh skor 0,019 lebih kecil dari 0,05. Tandatangani Hasil Tes di kelas eksperimen dan kelas kontrol.

Salah satunya adalah kreativitas melalui pembelajaran menggambar karena diyakini ada hubungan antara kemampuan menggambar dan kreativitas. Kegiatan menggambar menawarkan banyak aspek pendukung dalam pemikiran kreatif siswa (Chan dan Chan, 2007: 77).

Respon siswa terhadap penerapan pembelajaran menggambar berdasarkan pembelajaran di luar ruangan diperoleh rata-rata $83,05 \%$ dalam kategori sangat positif. Sebagian besar siswa menganggap pembelajaran di luar ruangan lebih menyenangkan, tidak membosankan, lebih termotivasi, dan lebih mudah menemukan ide atau ide dalam menggambar. Respons guru terhadap perangkat pembelajaran menggambar berbasis pembelajaran di luar ruangan adalah $85 \%$. Alat menggambar berbasis pembelajaran di luar ruangan ini dapat digunakan sebagai panduan bagi guru dalam mengembangkan alat belajar dalam materi pembelajaran lainnya dengan memanfaatkan media dan sumber belajar dari lingkungan.

\section{d. Pembelajaran Menggambar Berbasis Pembelajaran di Luar Ruangan Produk}

Perangkat pembelajaran menggambar berdasarkan pembelajaran di luar ruangan dalam bentuk buku panduan yang disusun dalam bentuk buku dengan ukuran kertas A4, tebal buku 72 halaman. Buku ini terdiri dari tiga bagian, yaitu halaman depan, konten dan halaman belakang. Halaman depan terdiri dari judul buku, kata pengantar, kata pengantar, dan daftar isi. Bagian 
konten terdiri dari 13 bab yaitu (1) instruksi untuk menggunakan RPP, (2) peralatan menggambar, (3) pembelajaran di luar ruangan, (4) kreativitas, (5) indikator pemetaan 1, (6) RPP 1, (7) tanaman di sekolah lingkungan, (8) indikator pemetaan 2, (9) RPP 2, (10) jenis pekerjaan, (11) indikator pemetaan 3, (12) RPP 3, (13) barang dan jasa. Halaman belakang terdiri dari bibliografi, biodata penulis, dan tinjauan isi buku. Buku panduan untuk menggambar pembelajaran adalah referensi pendidik dalam mengembangkan perangkat pembelajaran menggunakan pembelajaran di luar ruangan (Retnowati, 2009: 164). Manual perangkat pembelajaran menggambar berbasis Pembelajaran di Luar Ruangan berisi penjelasan / informasi tentang RPP, peralatan menggambar, pembelajaran di luar ruangan dan kreativitas untuk memberikan dukungan yang memadai bagi guru dalam mengembangkan dan menerapkan pembelajaran di luar ruangan (Derwing, Diepenbroek \& Foote, 2012: 36-37).

\section{Kesimpulan}

Kesimpulan dari penelitian ini adalah bahwa alat pembelajaran berbasis pembelajaran di luar ruangan dikembangkan sesuai dengan kriteria yang valid dan efektif untuk mengembangkan kreativitas siswa. Guru dapat menggunakan alat bantu belajar menggambar berbasis pembelajaran outdoor karena terbukti mampu mengembangkan kreativitas siswa. Siswa dapat menggunakan pembelajaran di luar ruangan untuk meningkatkan kreativitas.

Berdasarkan hasil pengembangan perangkat pembelajaran menggambar berbasis pembelajaran di luar ruangan, diharapkan guru atau peneliti selanjutnya dapat melakukan penelitian dan pengembangan pada perangkat pembelajaran yang berisi semua mata pelajaran dalam tema dan sub-tema yang ada sehingga dapat lebih sempurna. bekerja, selain itu penelitian juga perlu di sekolah lain sehingga temuan yang lebih beragam dapat diperoleh dan sampel penelitian dapat lebih representatif.

\section{Daftar Pustaka}

Arikunto, S. 2010. Jakarta: Rineka Cipta.

Bruner. 1977. Proses Pendidikan. Cambridge: Harvard University Press.

Chan, DW, \& Chan, LK 2007. Kreativitas dan Kemampuan Menggambar Siswa Tiongkok di Hong Kong: Apakah Ada Koneksi ?. Cakrawala Baru dalam Pendidikan. 55 (3): 77-94

Fagerstam, E., \& Samuelsson, J. 2012. Belajar Aritmatika Di Luar Rumah di Sekolah Menengah Pertama - Pengaruh pada Kinerja dan Keterampilan Mengatur Diri.

Hamalik, O. 2004. Proses Belajar Mengajar. Jakarta: Bumi Aksara.

Husamah. 2013. Pembelajaran Luar Kelas Pembelajaran Luar Ruang. Jakarta: Prestasi Pustakarya.

Kemendikbud. 2013. Permendikbud Nomor 81A tentang Implementasi Kurikulum. Jakarta: Kementerian Pendidikan dan Kebudayaan.

Komalasari, K. 2013. Pembelajaran Kontekstual Konsep dan Aplikasi. Bandung: Refika Aditama. Mardapi, D. 2012. Pengukuran, Penilaian dan Evaluasi Pendidikan. Yogyakarta: Nuha Medika.

Munandar, U. 2012. Pengembangan Kreatifitas Anak Berbakat. Jakarta: Rineka Cipta.

Rachmawati, N. 2013. Pengembangan Perangkat Pembelajaran IPS Terpadu Berbasis Outdoor Learning. Jurnal Pendidikan Dasar. 2 (2): 77-83.

Retnowati, TH 2009. Pengembangan Instrumen Penilaian Seni Lukis Anak di Sekolah Dasar. Disertasi. Yogyakarta: Program Pascasarjana Universitas Negeri Yogyakarta.

Sadiman, AS 1990. Media Pendidikan Pengertian, Pengembangan, dan Pemanfaatannya. Jakarta: Rajawali.

Sugiyono. 2013. Metode Penelitian Pendidikan Kuantitif, Kualitatif, dan R\&D. Bandung: Alfabeta.

Tabrani, P. 2014. Proses Kreasi Gambar Anak Proses Belajar. Jakarta: Erlangga. 
Thiagarajan, S., Semmel, DS, \& Semmel, MI 1974. Pengembangan Instruksional untuk Pelatihan Guru Anak Luar Biasa: Buku Sumber. Minnesota: Lembaga Pelatihan Kepemimpinan / Pendidikan Khusus, Universitas Minnesota.

Trnova, E. 2014. IBSE dan Pengembangan Kreativitas. Ilmu Pendidikan Internasional. 25 (1): 8-18.

Zwick, TT, \& Miller, KW 1996. Perbandingan Kegiatan Pendidikan Luar Ruang Terpadu dan Pembelajaran Sains Tradisional dengan Siswa Indian Amerika. Jurnal Pendidikan Indian Amerika. 35 (2): 1-9. 